\title{
Anticancer activity of new molecular hybrids combining 1,4-naphthalenedione motif with phosphonic acid moiety in hepatocellular carcinoma HepG2 cells
}

\author{
Angelika Długosz'1, Katarzyna Gach1, Jacek Szymański², Jakub Modranka³, Tomasz Janecki³ \\ and Anna Janecka ${ }^{1 凶}$
}

1Department of Biomolecular Chemistry, Faculty of Medicine, Medicinal University of Lodz, Łódź, Poland; ${ }^{2}$ Central Scientific Laboratory, Division of Public Health, Faculty of Health Sciences, Medical University of Lodz, Łódź, Poland; ${ }^{3}$ Institute of Organic Chemistry, Faculty of Chemistry, Lodz University of Technology, Łódź, Poland

Structural motifs found in naturally occurring compounds are frequently used by researchers to develop novel synthetic drug candidates. Some of these new agents are hybrid molecules which are designed through a concept of combining more than one functional element. In this report, anticancer activity of new synthetic molecular hybrids, substituted 3-diethoxyphosphorylnaphtho[2,3-b]furan-4,9-diones and 3-diethoxyphosphorylbenzo[f]indole-4,9-diones, which integrate natural 1,4-naphtalenedione scaffold, present in several anticancer agents, with pharmacophoric phosphonate moiety, were tested against hepatocellular cell line HepG2. Cytotoxicity was examined using MTT assay. Two most potent compounds, furandione $\mathbf{8 a}$ and benzoindoldione $12 \mathrm{a}$, which reduced the number of viable HepG2 cells with the $I C_{50}$ values of $4.13 \mu \mathrm{M}$ and $5.9 \mu \mathrm{M}$, respectively, were selected for further research. These compounds decreased the mRNA expression levels of several genes: $B C l-2$, angiogenic vascular endothelial growth factor (VEGF), c-Fos, caspase-8 and increased the expression of Bax, caspase-3 and -9, c-Jun, p21, p53, as determined by quantitative real-time PCR. The ability of these compounds to induce apoptosis and DNA damage was studied by flow cytometry. The obtained data showed that the new compounds inhibited cell viability by increasing apoptosis and decreasing angiogenesis. Compound $8 \mathbf{a}$ was a much stronger apoptosis inducer as compared with 12a and strongly activated the intrinsic pathway of apoptosis, associated with the loss of mitochondrial membrane potential and changes in $\mathrm{Bax} / \mathrm{BCl}-$ 2 ratio. These findings show that the synthetic hybrids combining 1,4-naphthalenedione system and phosphonic acid moiety display potential to be further explored in the development of new anticancer agents.

Key words: MTT test, apoptosis, real-time PCR, flow cytometry

Received: 09 February, 2016; revised: 13 September, 2016; accepted: 15 September, 2016; available on-line: 04 November, 2016

\footnotetext{
e-mail: anna.janecka@umed.lodz.pl

Abbreviations: DMSO, dimethyl sulfoxide; ECM, extracellular matrix; ELISA, enzyme-linked immunosorbent assay; ER, estrogen receptor; FBS, fetal bovine serum; GAPDH, glyceraldehyde 3-phosphate dehydrogenase; MMP-9, metalloproteinase-9; MMPs, matrix metalloproteinases; MTT, 3-(4,5-dimethylthiazol-2-yl)-2,5-diphenyltetrazolium bromide; PBS, phosphate buffered saline; PI, propidium iodide; SDS, sodium dodecyl sulfate; TCA, trichloroacetic acid; TNF-a, tumor necrosis factor-alpha; uPA, urokinase plasminogen activator
}

\section{INTRODUCTION}

Hepatocellular carcinoma (HCC) is one of the most frequent causes of cancer-related deaths (Siegel et al., 2013; Siegel et al., 2014). This type of cancer is predominantly associated with hepatitis $B$ and $C$ virus infections (Liovet et al., 2003; Parkin et al., 2005). The most commonly offered therapy for patients with HCC is surgery, but only a small portion of patients are candidates for radical surgery of tumor at the time of diagnosis (Simonetti et al., 1997; Liovet et al., 2008; Ramalingman et al., 2008; Takayama et al., 2010). Therefore, chemotherapy is the most important treatment for advanced HCC and there is an urgent need for the development of efficient drugs since sorafenib, an approved drug for HCC, is effective only in approximately $30 \%$ of the patients (Bruix et al., 2011). The diagnosis of HCC still remains difficult and there are large gaps in our current understanding of underlying molecular mechanisms involved in the pathogenesis of HCC (Sanyal et al., 2010). The elucidation of these diverse mechanisms for the identification of novel drug targets has therefore been a major focus in medicine, and further research efforts are still needed for an increased understanding and for developing efficient treatment strategies.

The scaffold of 1,4-naphtalenedione (Fig. 1), usually ortho-condensed with one or two planar rings is a well known pharmacophoric unit present in many natural and synthetic compounds displaying cytotoxic activity. Such structural motif is present in a large group of antibiotics widely used in anticancer therapy, known as anthracyclines, the best known of which is doxorubicin.

On the other hand, organophosphorus compounds, in particular phosphonic acid derivatives, have found an important and well-recognized place in the search for new drug candidates. Their success as pharmacophores is based on several assumptions, e.g. that phosphonic acid derivatives could inhibit the process in which phosphate is involved or that phosphoryl group can mimic the tetrahedral intermediates formed in enzymatic reactions involving carboxyl group metabolism. These rationales have resulted in the design of some important drugs with anticancer activity, i.e. N-phosphonoacetyl-L-aspartic acid (PALA) (Fig. 1).

Recently, we described the synthesis of a series of new molecular hybrids combining both mentioned above elements, 1,4-naphtalenedione system and phosphonic acid moiety (Gach et al., 2016). Here, these novel compounds were tested in the MTT assay for their possible cytotoxic 


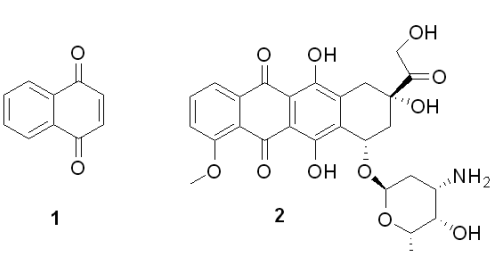<smiles>O=C(O)CC(=O)NC(CC(=O)O)C(=O)O</smiles>

Figure 1. The structure of: (1) 1,4-naphthalenedione, (2) doxorubicin, (3) N-phosphonoacetyl-L-aspartic acid (PALA).

activity in HepG2 cells. Among various hepatocellular carcinoma cell lines HepG2 is the one most extensively employed in the studies involving new drug candidates, since the cells preserve a large part of cellular functions of normal hepatocytes, including the expression of hepatocyte-specific cell surface receptors and synthesis of plasma proteins (Dehn et al., 2004). From the compounds screened in the MTT assay, two analogs with the lowest $\mathrm{IC}_{50}$ values were selected for further studies and their ability to regulate apoptosis and the level of the selected factors responsible for angiogenesis and metastasis was assessed.

\section{MATERIALS AND METHODS}

Materials and general procedures. 3-Diethoxyphosphorylnaphtho[2,3-b]furan-4,9-diones $8 \mathrm{a}-\mathrm{c}$ and 3-diethoxyphosphorylbenzo[f]indole-4,9-diones 12a-c were synthesized as outlined in the Scheme. Reaction of 2,3-dichloro-1,4-naphthoquinone 4 with diethyl acylmethylphosphonates 5a-c or ethyl diethoxyphosphorylacetate 9 , in the presence of base, gave corresponding substitution products 6 or 10 , respectively. Intramolecular cyclization of $\mathbf{6}$ via enol 7 furnished furanodiones $\mathbf{8 a}-\mathbf{c}$, whereas reaction of $\mathbf{1 0}$ with corresponding amines followed by intramolecular cyclization yielded benzoindolediones 12a-c (Scheme 1). The detailed procedures are described elsewhere (Gach et al., 2016).

Compounds were dissolved in DMSO and further diluted in the culture medium to obtain less than $0.1 \%$ DMSO concentration. In each experiment, controls without and with $0.1 \%$ DMSO were performed. $0.1 \%$ DMSO had no effect on the observed parameters.

Table 1. Primer sequences for real-time PCR

\begin{tabular}{|c|c|c|}
\hline \multirow{2}{*}{ Gene } & \multicolumn{2}{|l|}{ Primer sequences } \\
\hline & Forward primer & Reverse primer \\
\hline GAPDH & GTCGCTGTTGAAGTCAGAGGAG & CGTGTCAGTGGTGGACCTGAC \\
\hline $\mathrm{BCl}-2$ & CATGCTGGGGCCGTACAG & GAACCGGCACCTGCACAC \\
\hline$B A X$ & ACCCGGTGCCTCAGGATGCGT & GGCAAAGTAGAAAAGGGCGAC \\
\hline Cas-3 & TGAAGCTACCTCAAACTTCC & CAGCATCACTGTAACTTGCT \\
\hline Cas-8 & AGGAAAGTTGGACATCCTGAAAA & GGAGAGTCCGAGATTGTCATT \\
\hline Cas-9 & GTGACATCTITGTGTCCTAC & СТGTTATAAATCССТTТА \\
\hline VEGF & AAGGAGGAGGGCAGAATCAT & ATCTGCATGGTGATGTTGGA \\
\hline c-Fos & CGGGCTTCAACGCAGACTA & GGTCCGTGCAGAAGTCCTG \\
\hline c-Jun & TGCCTCCAAGTGCCGAAAAA & TGACTICTGTITAAGCTGCTCC \\
\hline p53 & СТСТCCCCAGCCAAAGAAGAA & CCACGGATCTGAAGGGTGAA \\
\hline p21 & GGCAGACCAGCATGACAGATT & GCGGATTAGGGCTTCCTCT \\
\hline
\end{tabular}

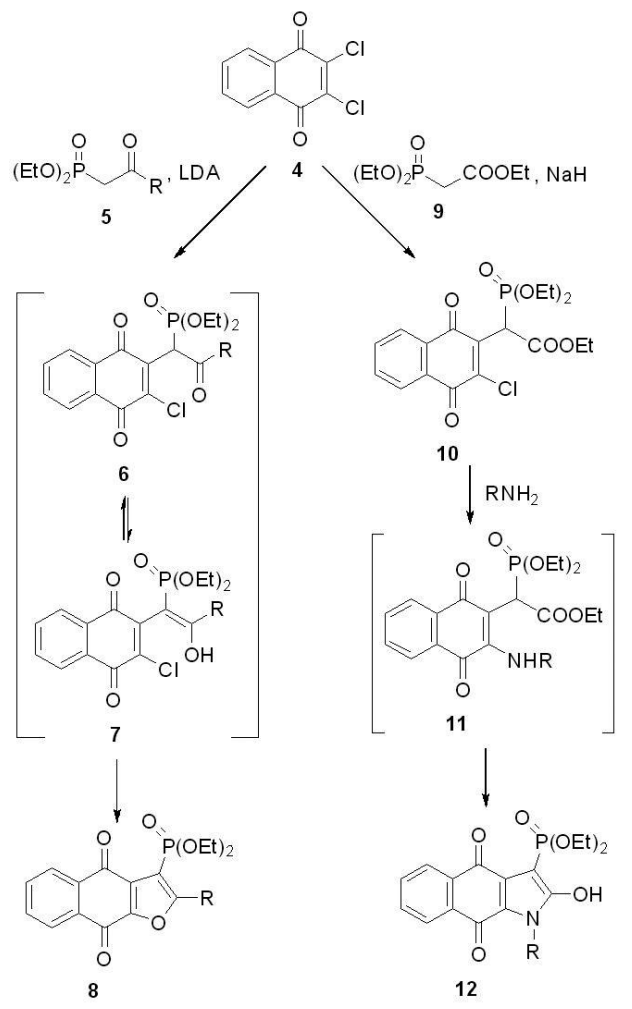

Scheme 1. Synthesis of 3-diethoxyphosphorylnaphtho[2,3-b] furan-4,9-diones 8 and 3-diethoxyphosphorylbenzo[f]indole-4,9diones 12.

Cell culture. Hepatocellular carcinoma cell line HepG2 was purchased from the European Collection of Cell Cultures (ECACC). The HepG2 cells were cultured in the Minimum Essential Medium Eagle (MEME, Sigma-Aldrich, St. Louis, MO, USA) supplemented with 10\% heat-inactivated fetal bovine serum (FBS) (Biological Industries, Beit-Haemek, Israel), $2 \mathrm{mM}$ glutamine (Sigma-Aldrich, Louis, MO, USA), Men Non-essential amino acid solution 100x (Sigma-Aldrich, St. Louis, MO, USA), gentamycin $(5 \mu \mathrm{g} / \mathrm{mL})$ (Biological Industries, Beit-Haemek, Israel). Cells were incubated in $37^{\circ} \mathrm{C}$, in a humidified atmosphere containing $95 \%$ air and $5 \% \mathrm{CO}_{2}$.

Cell viability assay (MTT). Cell growth and viability were measured by the MTT assay. The assay was performed according to the known procedure (Mosmann et al., 1983). Briefly, HepG 2 cells $\left(10^{4} /\right.$ per well) were seeded into 24-well plates (in $100 \mu \mathrm{l}$ ), left to adhere and grow for $24 \mathrm{~h}$. Various concentrations of the tested compounds were added and after $24 \mathrm{~h}$ the MTT solution $(5 \mathrm{mg} / \mathrm{ml}$ in phosphate buffered saline; PBS, Gibco, Invitrogen, Carlsbad, CA, USA) was added to each well. The plates were incubated for $2 \mathrm{~h}$ at $37^{\circ} \mathrm{C}$, then the medium was removed and $100 \mu \mathrm{l}$ of dimethyl sulfoxide (DMSO) was added to each well. The absorbance of the blue formazone product was measured at 540 nm using a iMark Bio-Rad microplate reader (Hercules, CA, USA). The $\mathrm{IC}_{50}$ values $(50 \%$ inhibitory concentration) were calculated.

Quantitative real-time PCR assay. Total RNA was extracted from HepG2 cells, using Total RNA Mini Kit (A\&A Biotechnology, Gdynia, Poland) accord- 
ing to the manufacturer's protocol (Chomczynski et al., 1987). The RNA concentration was determined by measuring the absorbance at 260, $280 \mathrm{~nm}$ on the UV/ VIS spectrophotometer (Pharmacia, Cambridge, UK). cDNA was synthesized using the Enhanced Avian HS RT-PCR Kit (St Louis, MO, USA). cDNA was amplified using Syber Green dye (Brilliant II SYBR Green) and gene specific primers (Table 1) in Stratagene MX3005P Real-time system (La-Jolla, California, USA). Real-time PCR cycles were run in triplicate using the following thermal cycling profile: $95^{\circ} \mathrm{C}$ for 10 min, followed by amplification was achieved by 40 cycles of denaturation at $95^{\circ} \mathrm{C}$ for $30 \mathrm{~s}$, annealing at $59^{\circ} \mathrm{C}$ for $45 \mathrm{~s}$ and extension at $72^{\circ} \mathrm{C}$ for $30 \mathrm{~s}$. The dissociation curve was inspected for quality control purposes.

The expression levels of the tested genes were determined by the $2^{-\triangle \Delta C T}$ method (Winer et al., 1999). Glyceraldehyde 3-phosphate dehydrogenase (GAPDH) was used as a reference gene.

Analysis of cell proliferation, apoptosis and DNA damage by flow cytometry. Cell proliferation, DNA damage and apoptosis were determined using the "Apoptosis, DNA Damage, and Cell Proliferation Kit" (BD Bioscience, San Jose, CA, USA), according to the manufacturer guidelines. The test kit includes: BD Cytofix/Cytoperm ${ }^{\text {TM }}$ Fixation/Permeabilization Solution; BD Perm/Wash ${ }^{\text {TM }}$ Buffer; BD Cytofix/Cytoperm ${ }^{\text {TM }}$ Plus Permeabilization Buffer, DAPI, BrdU, DNase and antibodies (PerCP-Cy ${ }^{\text {TM}} 5.5$ Mouse Anti-BrdU Alexa Fluor ${ }^{\circledR}$ 647 Mouse Anti-H2AX (pS139); PE Mouse Anti-Cleaved PARP (Asp214)).

Briefly, HepG2 cells were seeded in $25 \mathrm{~cm}^{2}$ cell culture flask at a density $8.0 \times 10^{4} / \mathrm{mL}$ in $10 \mathrm{~mL}$ of standard growth medium and left to grow for $24 \mathrm{~h}$. Then, the growth medium was replaced by a fresh growth medium supplemented with the tested compounds in the desired concentrations. After $24 \mathrm{~h}$ of incubation, the culture medium was collected and the floating cells were counted and discarded. Then, the fresh growth medium supplemented with BrdU (final concentration of $10 \mu \mathrm{M}$ ) was added to each flask for additional 8h. After incubation culture medium was collected and washed twice with phosphate buffered saline (PBS, GIBCO, Invitrogen, Carlsbad, CA, USA), harvested by trypsinization and centrifuged $(200 \times g, 5$ min). The total number of cells was determined. Cells were fixed, permeabilized according to the manufacturer's protocol and treated with DNase $(300 \mu \mathrm{g} / \mathrm{mL}$ in DPBS) for $1 \mathrm{~h}$ at $37^{\circ} \mathrm{C}$ in order to expose $\mathrm{BrdU}$ epitopes. After incubation, cells were simultaneously stained with fluorochrome-labeled anti-BrdU, H2AX (pS139) and cleaved PARP (Asp214) antibodies for 20 min at room temperature. After washing, DNA staining for cell cycle analysis using DAPI solution $(1 \mu \mathrm{g} /$ $\mathrm{mL}$ of staining buffer) was performed. Cell were resuspended in staining buffer and analyzed by flow cytomtery using (Becton Dickinson Canto II). The data was visualized and quantified by constructing a dotplot using the BD FACSDiva software.

Analysis of reactive oxygen species (ROS) induction by flow cytometry. Induction of ROS generation was determined by flow cytometry using the CellROX ${ }^{\circledR}$ Oxidative Stress Reagents (Molecular Probes; Life Technologies, Carlsbad, CA, USA) which are fluorogenic probes designed to reliably measure ROS in the live cells. The cell-permeable reagents are non-fluorescent or very weakly fluorescent in a reduced state but upon oxidation they exhibit a strong fluorogenic signal. Briefly, HepG2 cells were seeded in 6 -well cell culture plates at a density of $0.16 \times 10^{6} / \mathrm{ml}$ in $3 \mathrm{ml}$ of standard growth medium. After $24 \mathrm{~h}$, the growth medium was replaced by a fresh growth medium supplemented with the tested compounds in the desired concentrations. Then the cells were incubated with $5 \mu \mathrm{M}$ CellROX ${ }^{\circledR}$ Green and $5 \mu \mathrm{M}$ Reagents at $37^{\circ} \mathrm{C}$ for $30 \mathrm{~min}$ in the dark. After harvesting by trypsinization, centrifuged $(200 \times \mathrm{g}, 5 \mathrm{~min})$ and washed twice with PBS the were re-suspended in PBS and analyzed by flow cytometry (Becton Dickinson Canto II). Menadione was used as a positive control.

Statistical analysis. Statistical analyses were performed using Prism 4.0 (GraphPad Software Inc., San Diego, CA, USA). The data were expressed as means \pm SEM. Statistical comparisons were assessed by a one way ANOVA followed by a post-hoc multiple comparison Student-Newman-Keuls test. A probability level of 0.05 or lower was considered statistically significant.

\section{RESULTS}

\section{MTT assay}

Cytotoxic activity of the compounds was examined using the MTT assay. HepG2 cells were exposed to a board range of compound concentrations for $24 \mathrm{~h}$ ( Table 2). Compounds $\mathbf{8 a}$ and $\mathbf{1 2 a}$ showed the highest cytotoxic activity and were selected for further evaluation as potential anticancer agents.

Table 2. Growth inhibitory effects of novel chimeric derivatives in human hepatocellular cell line HepG2

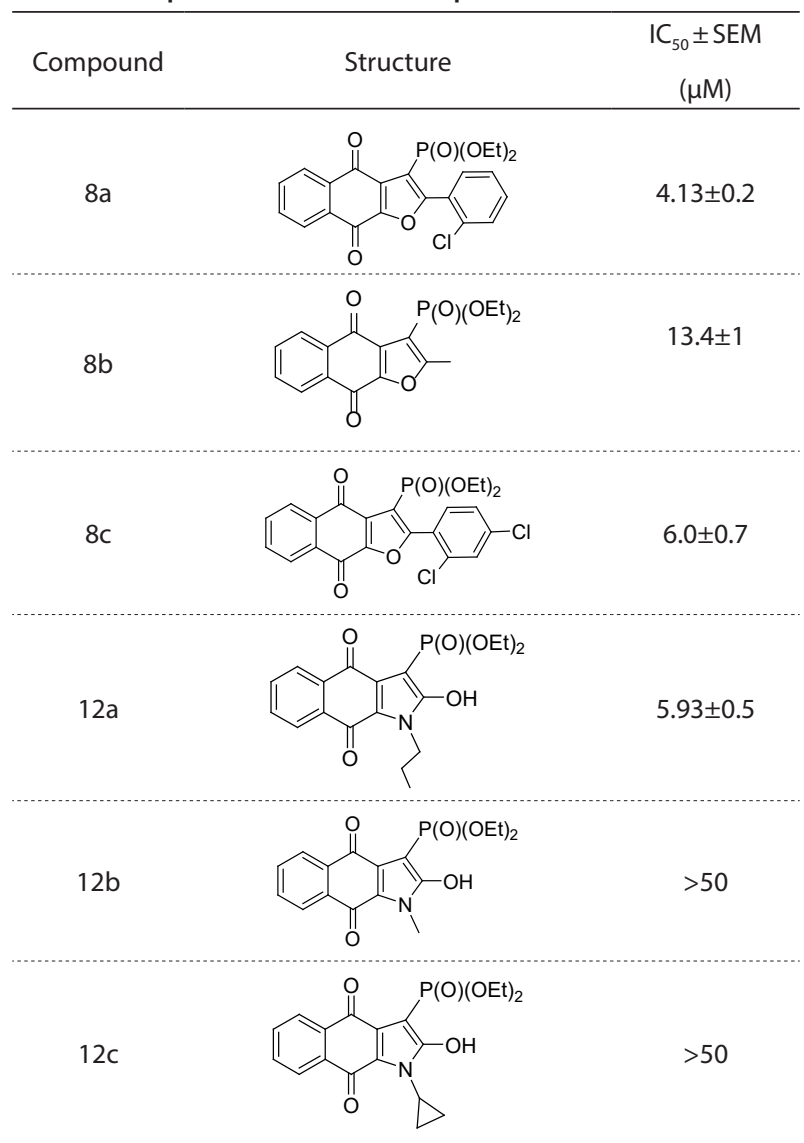

All values are expressed as mean \pm SEM of three independent experiments. 


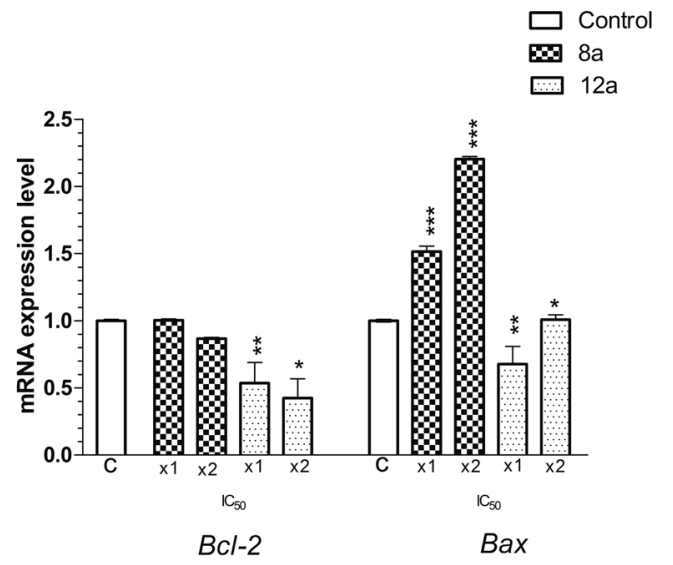

Figure 2. The change of the apoptosis-related gene expression in HepG2 treated with $8 \mathrm{a}$ and $12 \mathrm{a}$, detected by real time PCR. GAPDH was used as control.

The expression was calculated using the $2^{-\Delta \Delta C T}$ method. Data are means \pm SEM.

\section{Effect of $8 \mathrm{a}$ and $12 \mathrm{a}$ on expression levels of selected genes involved in apoptosis angiogenesis and metastasis}

The effect of $\mathbf{8} \mathbf{a}$ and $\mathbf{1 2} \mathbf{a}$ on the expression of several genes engaged in such cellular processes as apoptosis and angiogenesis was assessed using quantitative real-time PCR. The tested compounds were used in two concentrations $\left(\mathrm{IC}_{50}\right.$ and $\left.2 \mathrm{xIC}_{50}\right)$. Gene expression was normalized to the house keeping GAPDH gene. Analogs $8 \mathbf{a}$ and $12 \mathbf{a}$ caused down-regulation of the anti-apoptotic $B c l-2$ and caspase-8 and up-regulation of pro-apoptotic $B A X$, caspase-3 and -9 , $(p \leq 0.01)$ (Figs. 2 and 3). Both compounds were also shown to increase the mRNA levels of $p 21$ and $p 53$, two genes responsible for regulation of the cell cycle (Fig. 4).

As it is well known, some cancer cells acquire the ability to penetrate the walls of blood vessels and to circulate through the bloodstream to other tissues in the body. In malignant cells there is usually the overexpression of matrix metalloproteinases (MMP) which are enzymes involved in the breakdown of extracellular matrix and enable cancer cells to form metastasis. When a new tumor is formed, it needs a supply of nutrients and oxygen. Vascular endothelial growth factor (VEGF), is a signal protein produced by cells that stimulates angiogenesis

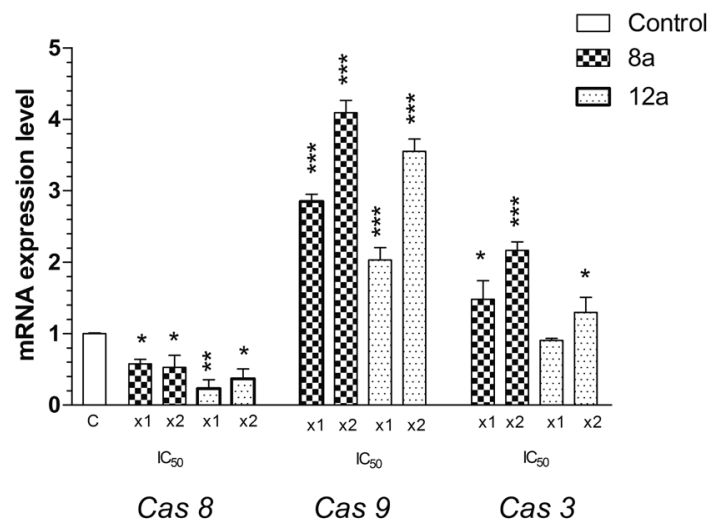

Figure 3. The expression levels of Caspase 9, Caspase 3 and Caspase 8 genes in HepG2 treated with $8 \mathrm{a}$ and $12 \mathrm{a}$.

Expression was detected by real time PCR. GAPDH was used as control. The expression was calculated using the $2^{-\Delta \Delta C T}$ method. Data are means \pm SEM.

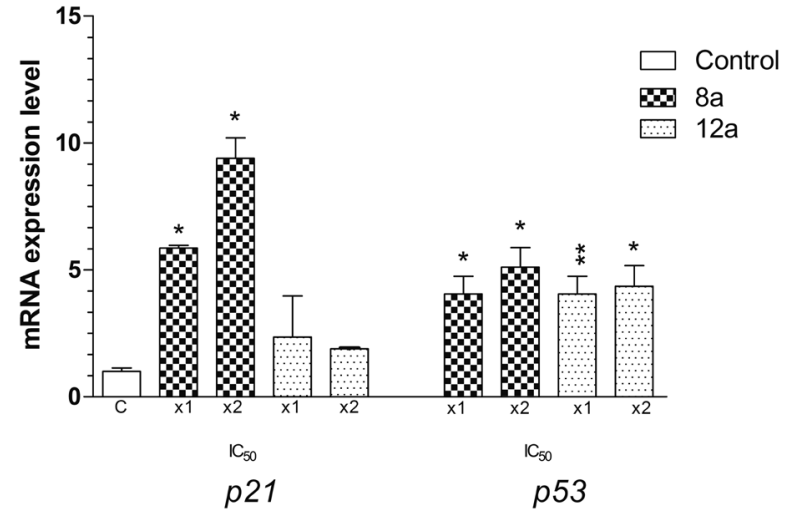

Figure 4. The expression levels of $p 21$ and $p 53$ genes in HepG2 cells treated with $8 \mathrm{a}$ and $12 \mathrm{a}$.

Expression was detected by real time PCR. GAPDH was used as control. The expression was calculated using the $2^{-\Delta \Delta C T}$ method. Data are means \pm SEM.

and in normal cells is a part of the system that restores the oxygen supply to tissues when blood circulation is inadequate. In cancer cells overexpression of VEGF may be an early step in the process of metastasis and is often implicated with poor prognosis. $8 \mathrm{a}$ and $12 \mathrm{a}$ were shown to only slightly decrease the mRNA expression of MMP9 (Fig. 5) but caused a significant down-regulation of VEGF as compared with control (Fig. 6).

The influence of both tested compounds on the expression of two transcription factors, c-Fos and c-Jun was also investigated. As shown in Fig. 7, the tested compounds down-regulated c-Fos but increased c-Jun expression. These transcriptional factors are regulated by the mitogen-activated protein kinase (MAPK) which promotes cell survival and proliferation. The stimulation of c-Fos involves a signal transduction pathway, which includes activation of the small $G$ protein Ras, Raf-1 kinase and the mitogen-activated protein (MAP) kinases, and extracellular-signal-regulated kinases (ERK1 and ERK2) (Kondoh et al., 2007). The c-Fos is a proto-oncogene, known as a third intracellular messenger. It encodes a $62 \mathrm{kDa}$ protein, which can form a homo-dimers or hetero-dimers with Jun family of transcription factors, resulting in the formation of Activator Protein-1 (AP-1). It has been reported that the promoter region for the VEGF gene contains several AP-1 binding motifs and the expression of VEGF is controlled by transcription

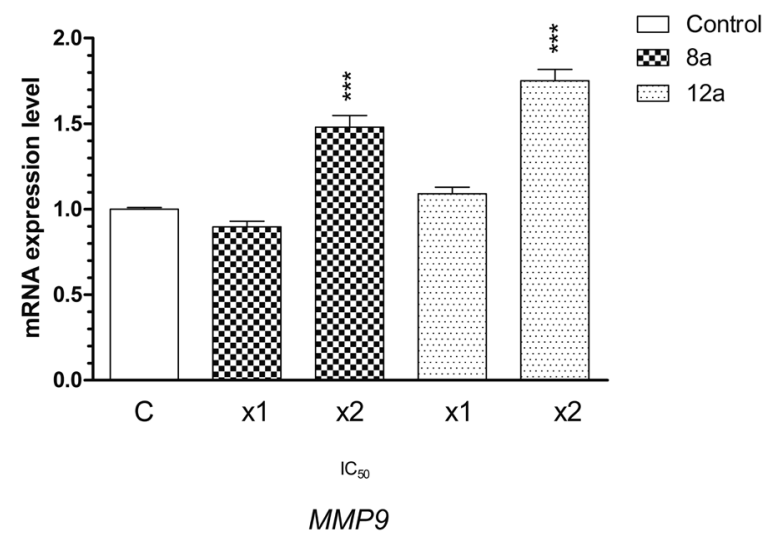

Figure 5. The expression levels of metalloproteinase-9 (MMP9) gene HepG2 cells treated with $8 a$ and $12 a$, detected by real time PCR.

GAPDH was used as control. The expression was calculated using the $2^{-\Delta \Delta C T}$ method. Data are expressed as means \pm SEM. 


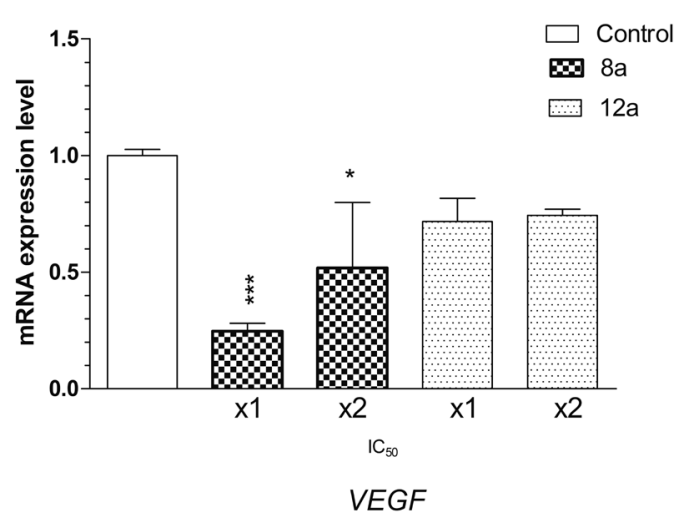

Figure 6. The expression levels of vascular endothelial growth factor (VEGF) gene in HepG2 cells treated with 8a and 12a.

Expression was detected by real time PCR. GAPDH was used as control. The expression was calculated using the $2^{-\Delta \Delta C T}$ method. Data are expressed as means \pm SEM.

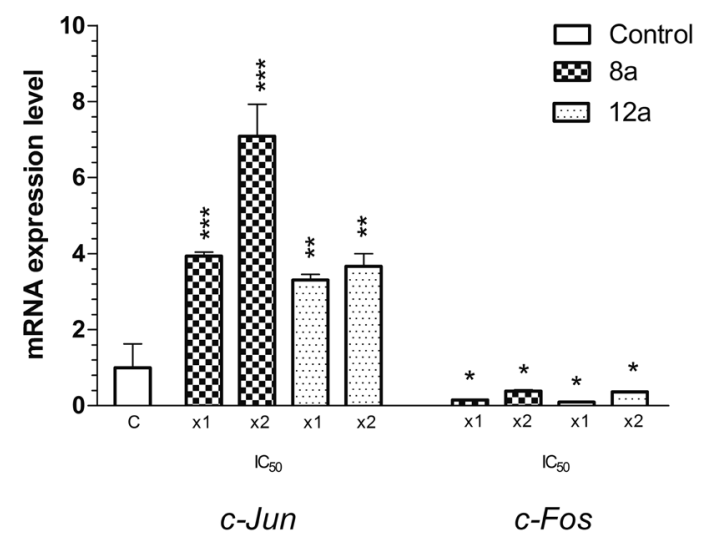

Figure 7. The expression levels of c-Jun and c-Fos transcription factor genes in HepG2 cells treated with $8 \mathrm{a}$ and 12a.

Expression was detected by real time PCR. GAPDH was used as

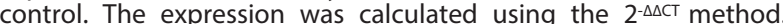
Data are expressed as means \pm SEM.

factors AP-1 and AP-2. As demonstrated in Figs. 6 and 7, VEGF and c-Fos mRNA expression was decreased in cells incubated with the tested compounds as compared with control, confirming the relationship between these two genes (Collado et al., 2005).

The stimulation of c-Jun involves the signal transduction pathway, which includes activation of the c-Jun $\mathrm{N}$ terminal kinase (JNK) group of MAP-kinases. The expression of c-Jun is regulated by diverse extracellular stimuli, such as pro-inflammatory cytokines or oxidative and cellular stress. Especially the JNK pathway has been implicated in apoptotic responses to DNA damage, cell stress and cytotoxic drugs (Gurzov et al., 2008). In our experiments, the up-regulation of c-Jun mRNA expression resulted in the increased number of apoptotic (Fig. 7) and DNA damage-positive cells.

\section{Effect of $8 \mathrm{a}$ and $12 \mathrm{a}$ on apoptosis by flow cytometry using Annexin V-FITC and propidium iodide (PI) double staining}

HepG2 cells were tested for $48 \mathrm{~h}$ with $\mathbf{8 a}$ and $\mathbf{1 2 a}$ at $\mathrm{IC}_{50}$ concentration. Annexin V/PI analysis was performed to quantify apoptotic phenotype. Analysis by flow cytometry showed that $\mathbf{8 a}$ induced late apoptosis in HepG2 cells but did not change the number

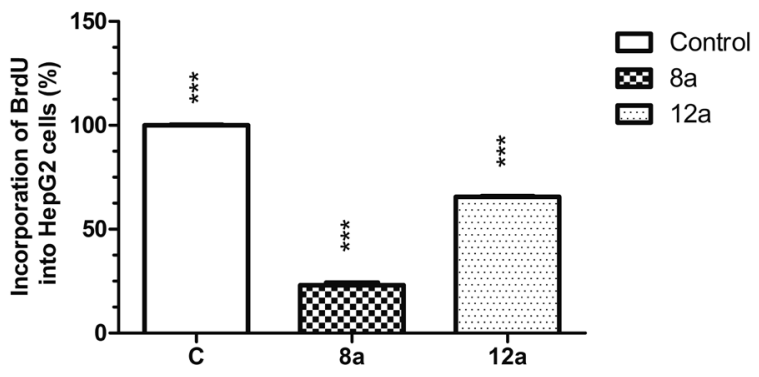

Figure 8. Incorporation of BrdU (BrdU test)

Inhibition of cell proliferation in HepG2 cells incubated for $48 \mathrm{~h}$ with $8 \mathrm{a}$ and $12 \mathrm{a}$ at $I C_{50}$ concentration and treated with BrdU for additional $8 \mathrm{~h}$. Fluorochrome-labeled anti-BrdU antibodies were added and allowed to stand for $20 \mathrm{~min}$ at room temperature. Results were analyzed by flow cytometry. Data represent mean \pm SEM. Statistical significance was assessed using one-way ANOVA and a post-hoc multiple comparison Student-Newman-Keuls test. ${ }^{*} p<0.05,{ }^{* *} p<0.01,{ }^{* *} p<0.001$.

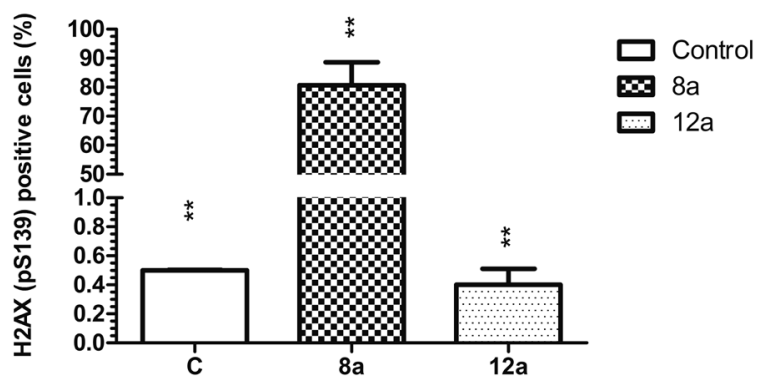

Figure 9. DNA damage ( $\mathrm{H} 2 \mathrm{AX}$ test)

DNA damage ( $\mathrm{H} 2 \mathrm{AX}$ test) in HepG2 cells incubated for $48 \mathrm{~h}$ with $\mathbf{8 a}$ and $12 \mathbf{a}$ at $I C_{50}$ concentration. Fluorochrome-labeled antiH2AX (pS139) antibodies were added to HepG2 cells and allowed to stand for $20 \mathrm{~min}$ at room temperature. Results were analyzed by flow cytometry. Data represent mean \pm SEM. Statistical significance was assessed using one-way ANOVA and a post-hoc multiple comparison Student-Newman-Keuls test. ${ }^{*} p<0.05,{ }^{* *} p<0.01$, ${ }^{* * *} p<0.001$.

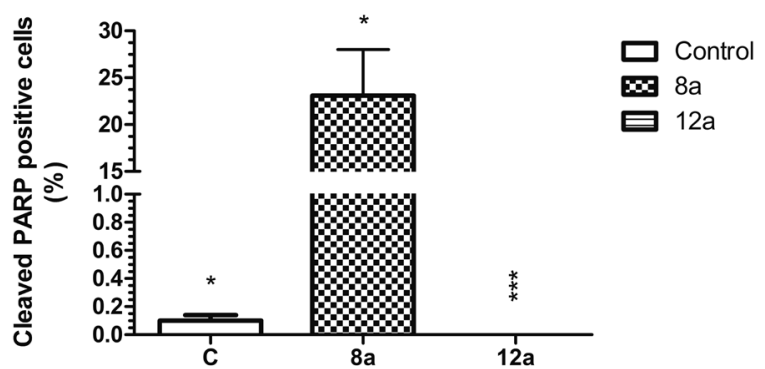

Figure 10. Induction of apoptosis (PARP test)

Induction of apoptosis (PAPR test) in HepG2 cells incubated for $48 \mathrm{~h}$ with $\mathbf{8} \mathbf{a}$ and $12 \mathbf{a}$ at $I C_{50}$ concentration. Fluorochrome-labeled anticleaved (Asp214) antibodies were added and $89 \mathrm{kDa}$-cleaved fragment of PARP served as a marker of cellular apoptosis. Results were analyzed by flow cytometry. Data represent mean \pm SEM. Statistical significance was assessed using one-way ANOVA and a post-hoc multiple comparison Student-Newman-Keuls test. ${ }^{* *} p<0.01,{ }^{* * *} p<0.001$.

of early apoptotic cells (Table 3). By contrast, 12a did not produce significant changes as compared to control. The number of late apoptotic cells increased up to $77.2 \pm 2.3 \%$ when incubated with $8 \mathrm{a}$ and to $9.5 \pm 3.2 * * * 0 \%$ in 12a treated cells as compared with control. Incubation with $8 \mathbf{a}$ and $12 \mathbf{a}$ enhanced also the number of necrotic cells. 
Table 3. Effect of tested compounds on apoptosis induction in HepG2 cells.

\begin{tabular}{lllll}
\hline Compound & Necrosis & Late apoptosis & Early apoptosis & Healthy cells \\
\hline Control & $10.1 \pm 0.8^{*}$ & $13.2 \pm 1.6^{* * *}$ & $0.8 \pm 0.3^{*}$ & $57.5 \pm 1.2^{* * *}$ \\
\hdashline $8 \mathrm{a}$ & $3.6 \pm 1.1$ & $77.2 \pm 2.3$ & $0.7 \pm 0.2^{*}$ & $1.7 \pm 0.1^{* *}$ \\
\hline $12 \mathrm{a}$ & $4.1 \pm 0.8^{*}$ & $9.5 \pm 3.2^{* * *}$ & $1.6 \pm 1.3$ & $44.1^{*} 0.6^{* * *}$ \\
\hline
\end{tabular}

Data represent percentage of cells in each step of apoptosis. Values are mean \pm SEM of three independent experiments. Statistical significance was assessed using one-way ANOVA and a post hoc multiple comparison Student-Newman-Keuls test. ${ }^{*} p<0.05,{ }^{* *} p<0.01$, and ${ }^{* *} p<0.001$.
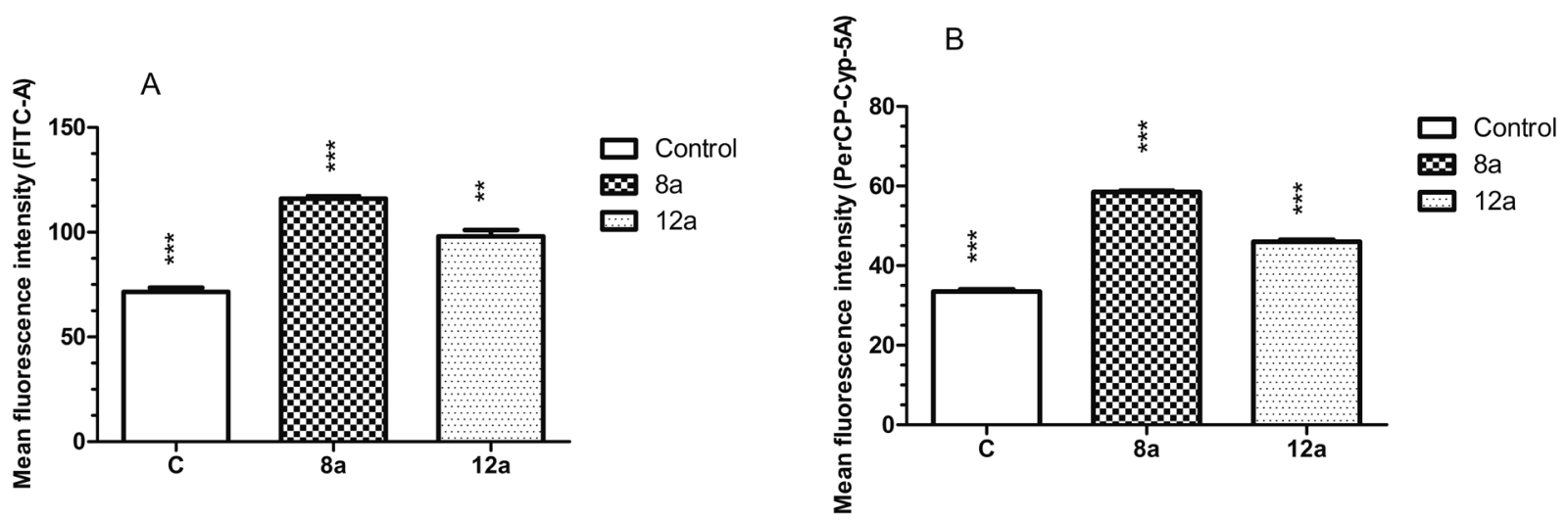

Figure 11. Generation of ROS in nucleus and mitochondria (A) and in cytoplasm (B) in HepG2 cells incubated for $48 \mathrm{~h}$ with $8 \mathrm{a}$ and $12 \mathrm{a}$ at $I C_{50}$ concentration.

The cells were treated with $5 \mu \mathrm{M}$ CellROX ${ }^{\circledR}$ Green Reagent and $5 \mu \mathrm{M}$ CellROX ${ }^{\circledR}$ Red Reagent in a $37^{\circ} \mathrm{C}$ for 30 min. Data represent mean \pm SEM. Statistical significance was assessed using one-way ANOVA and a post-hoc multiple comparison Student-Newman-Keuls test. ${ }^{*} p<0.05$, ${ }^{* *} p<0.01$, and ${ }^{* * *} p<0.001$.

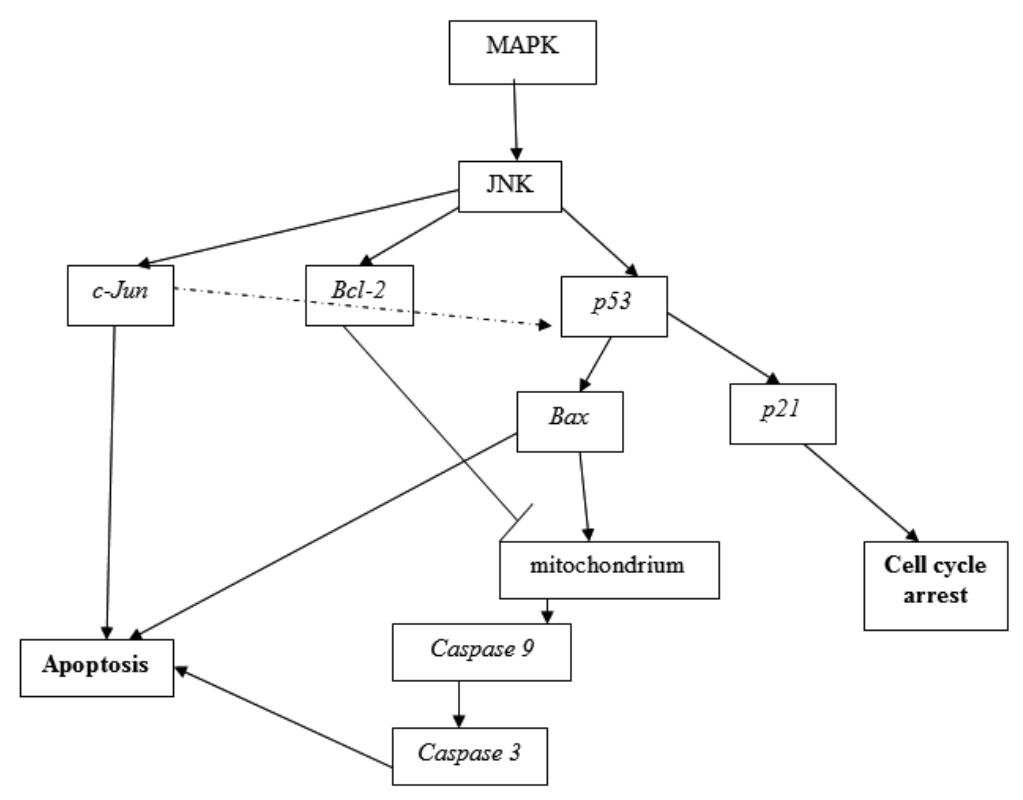

Figure 12. The possible pathways leading to HepG2 cell apoptosis induced by 8 a.

\section{Inhibition of cell proliferation, induction of DNA damage and apoptosis}

The ability of $\mathbf{8} \mathbf{a}$ and $\mathbf{1 2 a}$ to inhibit cell proliferation, generate DNA damage and induce apoptotic cell death was also examined by flow cytometry using the 'Apoptosis, DNA Damage, and Cell Proliferation Kit' (BD Bioscience). The obtained results demonstrated that $\mathbf{8 a}$ significantly inhibited proliferation in about $76.8 \%$ of cell population, while $12 \mathrm{a}$ only in $34.5 \%$ (Fig. 8). 8a gener- ated DNA damage in $80.7 \%$ of cells, while 12a had no effect in this test (Fig. 9). Only 8a significantly increased the number of cleaved PARP positive (apoptotic) cells (up to $23.1 \%$ compared with control $0.1 \%$ ) (Fig. 10).

\section{Effect of $8 a$ and $12 a$ on reactive oxygen species (ROS) generation}

One of the possible mechanisms of the cytotoxic activity of compounds with 1,4-naphtalenedione scaffold can be associated with generation of reactive oxygen species (ROS) in cancer cells. As shown in Fig. 11, the tested compounds only slightly increased intracellular ROS levels, as compared with control.

\section{DISCUSSION}

Simple synthetic compounds based on the motifs present in natural products may become attractive drug candidates. Continuing our studies on hybrid molecules combining 1,4-naphthalenedione motif with phosphonic acid moiety we investigated the anticancer activity of 3-diethoxyphosphorylnaphtho[2,3-b]furan-4,9-dione $\mathbf{8 a}$ and 3-diethoxyphosphorylbenzo[f]indole-4,9-dione 12a in vitro against human hepatocellular carcinoma HepG2 cell line. Both compounds showed high cytotoxic activity with the $\mathrm{IC}_{50}$ values below $10 \mu \mathrm{M}$ but and $8 \mathbf{a}$ was much more active in inducing apoptosis, the process that can be induced by different pathways. As it is well recognized, activation of MAPK phosphatases leads to the 
phosphorylation and induction of MAP kinase signaling pathway. The members of the MAPK, involving a series of protein kinase cascades, play a critical role in regulation of cell proliferation, differentiation, stress response, apoptosis and survival (Plotnikov et al., 2011; Yang et al., 2013).

The first identified MAPK was c-Jun N-terminal kinase (JNK) (Derijard et al., 1994; Kyriakis et al., 1994). The crucial role of $\mathrm{JNK}$ is phosphorylation and activation of protein 1 (AP-1) family, which consist of Fos (encoded by the c-Fos gene), Jun (encoded by the c-Jun gene) and activating transcription factor 2 (ATF-2) subfamilies. Finally, activation of JNK and c-Jun/AP-1 can contribute to apoptosis (Takeda et al., 2004; Matsuzawa et al., 2005).

Despite a function of $\mathrm{JNK}$ in the regulation of c-Jun, this kinase may also regulate and control the p53 pathway by ability to phosphorylate p53 protein. Additionally, c-Jun may control cell cycle in a p53-dependent manner and N-terminal-JNK can be the functional inducer in $p 53$ transcriptional activity (Waldman et al., 1995; Wisdom et al., 1999; Buschmann et al., 2000; Cheng et al., 2003; Danasekaran et al., 2008).

The p53 protein plays a significant role in modulation the cell cycle by induction the G1-, S-, or G2-phase arrest or stimulation apoptosis when DNA is damaged. Transactivation of $p 21$ is required for the p53-dependent G1 checkpoint (Waldman et al., 1995; Abbas et al., 2009).

The p53-induced apoptosis can also involve the activation of a proapoptotic gene, Bax (Miyashita et al., 1995). By phosphorylation-dependent posttranslational, proapoptotic processes, JNK can contribute to transcription of the members of apoptotic signaling pathway, leading to inactivation of $\mathrm{Bcl}-2$ promoter.

JNK and p53 pathways may cooperate in induction of apoptotic mitochondrial events which include activation of $B a x$ and $B a k$, inactivation of $B c l-2$ and disrupt the mitochondrial outer membrane. Finally, the cytochrome $c$ released from the mitochondria promotes induction of the caspase 9, leading to caspase 3 activation and apoptosis (Kharbanda et al., 2000; Verhagen et al., 2000; Cory et al., 2002; Adams et al., 2007; Elmore et al., 2007; Danasekaran et al., 2008; Ahn et al., 2011). The graph in Fig. 12 shows the possible pathways leading to HepG2 cell apoptosis induced by $\mathbf{8 a}$.

\section{Acknowledgements}

Financial support from the Medical University of Lodz (No 503/1-156-02/503-11-002 and 502-03/1-15602/502-14-300) and Lodz University of Technology (statutory founds I-18/13/DzS)

\section{REFERENCES}

Abbas T, Dutta A (2009) p21 in cancer: intricate networks and multiple activities. Nat Rev Cancer 9: 400-414. http://dx.doi.org/10.1038/ nrc2657

Adams JM, Cory S (2007) The Bcl-2 apoptotic switch in cancer development and therapy. Oncogene 26: 13241337. http://dx.doi.org/ $10.1038 /$ si.onc. 1210220

Ahn HJ, Kim KI, Kim G, Moon E, Yang SS, Lee JS (2011) Atmospheric-pressure plasma jet induces apoptosis involving mitochondria via generation of free radicals. PLOS One 6: e28154. http:// dx.doi.org/ 10.1371/journal.pone.0028154

Bruix J, Sherman M (2011) American Association for the Study of Liver Diseases. Management of hepatocellular carcinoma: an update. Hepatology 53: 1020-1022. http://dx.doi.org/10.1002/hep.24199

Buschmann T, Yin Z, Bhoumik A, Ronai Z (2000) Amino-terminal-derived JNK fragment alters expression and activity of c-Jun, ATF2, and p53 and increases H2O2-induced cell death. JBiol Chem 275: 16590-16596. http://dx.doi.org/ 0.1074/jbc.M910045199
Cheng WH, Zheng X, Quimby FR, Roneker CA, Lei XG (2003) Low levels of glutathione per-oxidase 1 activity in selenium-deficient mouse liver affect c-Jun N-terminal kinase activa-tion and p53 phosphorylation on Ser-15 in pro-oxidant-induced aponecrosis. Biochem I 370: 927-934. http://dx.doi.org/ 10.1042/bj20021870

Chomczynski P, Sacchi N (1987) Single-step method of RNA isolation by acid guanidinium thiocyanate-phenol-chloroform extraction. Anal Biochem 162: 156-159. http://dx.doi.org/10.1016/00032697(87)90021-2

Collado B, Sánchez MG, Díaz-Laviada I, Prieto JC, Carmena MJ (2005) Vasoactive intestinal peptide (VIP) induces c-fos expression in $\mathrm{LNCaP}$ prostate cancer cells through a mechanism that involves $\mathrm{Ca}^{2+}$ signalling. Implications in angiogenesis and neuroendocrine differentiation. Biochimica et Biophysica Acta (BBA) - Molecular Cell 2: 224-233. http://dx.doi.org/10.1016/j.bbamcr.2005.04.009

Cory S, Adams JM (2002) The Bcl2 family: Regulators of the cellular life-or-death switch. Nat Rev Cancer 2: 647-656. http://dx.doi.org/ $10.1038 / \mathrm{nrc} 883$

Dehn PF, White CM, Conners DE, Shipkey G, Cumbo TA (2004) Characterization of the human hepatocellular carcinoma (hepg2) cell line as an in vitro model for cadmium toxicity studies. In Vitro Cell Dev Biol Anim 40: 172-182. http://dx.doi.org/10.1290\%2F1543-70 6X(2004) $40<172 \% 3$ ACOTHHC $>2.0 . \mathrm{CO} \% 3 \mathrm{~B} 2$

Dérijard B, Hibi M, Wu IH, Barrett T, Su B, Deng T, Karin M, Davis RJ (1994) JNK1: a protein kinase stimulated by UV light and $\mathrm{Ha}-$ Ras that binds and phosphorylates the c-Jun activation domain. Cell 76: 1025-1037. http://dx.doi.org/10.1016/0092-8674(94)90380-8

Dhanasekaran DN, Reddy EP (2008) JNK signaling in apoptosis. Oncogene 27: 6245-6251. http://dx.doi.org/ 10.1038/onc.2008.301

Elmore S (2007) Apoptosis: A review of programmed ell death. Toxicol Pathol 35: 495-516. http://dx.doi.org/10.1080\%2F01926230701320337

Gach K, Modranka J, Szamański J, Pomorska D, Krajeńska U, Janecki T, Janecka A (2016) Anticancer properties of new synthetic hybrid molecules combining naphtha[2,3-b]furan-4,9-dione or benzo[f] indole-4,9-dione motif with phosphonate subunit. Eur J Med Chem 120: 51-63. http://dx.doi:10.1016/j.ejmech.2016.05.002.

Gurzov EN, Bakiri L, Alfaro JM, Wagner EF, Izquierdo M (2008) Targeting c-Jun and JunB proteins as potential anticancer. Oncogene 27: 641-652. http://dx.doi.org/ 10.1038/sj.onc.1210690

Kharbanda S, Pandey P, Yamauchi T, Kumar S, Kaneki M, Kumar V (2000) Activation of MEK kinase 1 by the c-Abl protein tyrosine kinase in response to DNA damage. Mol Cell Biol 20: 4979-4989. http://mcb.asm.org/content/20/14/4979.full.pdf

Kondoh K, Nishida E (2007) Regulation of MAP kinases by MAP kinase phosphatases. Biochim Biophys Acta 1773: 1227-1237. http:// dx.doi.org/10.1016/j.bbamcr.2006.12.002

Kyriakis JM, Banerjee P, Nikolakaki E, Dai T, Rubie EA, Ahmad MF, Avruch J, Woodgett JR (1994) The stress-activated protein kinase subfamily of c-Jun kinases. Nature 369: 156-160. http://dx.doi.org/ $10.1038 / 369156 \mathrm{a} 0$

Llovet JM, Bruix J (2008) Novel advancements in the management of hepatocellular carcinoma in 2008. J Hepatol 48: 1: 2037. http://dx. doi.org/10.1016/j.jhep.2008.01.022.

Llovet JM, Burroughs A, Bruix J (2003) Hepatocellular carcinoma. Lancet 362: 1907-1917. http://dx.doi.org/10.1016/S01406736(03)14964-1

Matsuzawa A, Saegusa K, Noguchi T, Sadamitsu C, Nishitoh H, Nagai S (2005) ROS-dependent activation of the TRAF6-ASK1-p38 pathway is selectively required for TLR4-mediated innate immunity. Nat Immunol 6: 587-592. http://dx.doi.org/ 10.1038/ni1200

Miyashita T, Kitada S, Krajewski S, Horne WA, Delia D, Reed JC (1995) Overexpression of the Bcl-2 protein increases the half-life of p21Bax. J Biol Chem 270: 26049-26052. http://dx.doi.org/10.1074/ jbc. 270.44 .26049

Mosmann T (1983) Rapid colorimetric assay for cellular growth and survival: application to proliferation and cytotoxicity assays. I Immunol Methods 65: 55-63. http://dx.doi.org/10.1016/00221759(83)90303-4

Parkin DM, Bray F, Ferlay J, Pisani P (2005) Global cancer statistics. CA Cancer J Clin 55: 74-108. http://dx.doi.org/10.3322/canjclin.55.2.74

Plotnikov A, Zehorai E, Procaccia S, Seger R (2011) The MAPK cascades: signaling components, nuclear roles and mechanisms of nuclear translocation. Biochim Biophys Acta 1813: 1619-1633. http:// dx.doi.org/ 10.1016/j.bbamcr.2010.12.012

Ramalingam S, Belani C (2008) Systemic chemotherapy for advanced non-small cell lung cancer: recent advances and future directions. Oncologist 13: 5-13. http://dx.doi.org/10.1634/theoncologist.13-S1-5

Sanyal AJ, Yoon SK, Lencioni R (2010) The etiology of hepatocellular carcinoma and consequences for treatment. Oncologist 154: 14-22. http://dx.doi.org/ 10.1634/theoncologist.2010-S4-14

Siegel R, Naishadham D, Jemal A (2013) Cancer statistics 2013. CA Cancer I Clin 63: 11-30. http://dx.doi.org/10.3322/caac.21166

Siegel RL, Fedewa SA, Miller KD, Goding-Sauer A, Pinheiro PS, Martinez-Tyson D (2015) Cancer statistics for Hispanics/Latinos. CA Cancer J Clin 16. http://dx.doi.org/10.3322/caac.21314 
Simonetti RG, Liberati A, Angiolini C, Pagliaro L (1997) Treatment of hepatocellular carcinoma: a systematic review of randomized controlled trials. Ann. Oncol 8: 117-136. http://dx.doi. org/10.1023/A:1008285123736

Takayama T, Makuuchi M, Hasegawa K (2010) Single HCC smaller than $2 \mathrm{~cm}$ : surgery or ablation?: surgeon's perspective. J. Hepatobiliary Pancreat Sci 17: 422-424. http://dx.doi.org/10.3748\%2Fwjg.v20. i29.10174

Takeda K, Matsuzawa A, Nishitoh H, Tobiume K, Kishida S, Ninomiya-Tsuji J (2004) Involvement of ASK1 in $\mathrm{Ca}^{2+}$-induced p38 MAP kinase activation. EMBO Rep 5: 161-166. http://dx.doi.org/ 10.1038/sj.embor.7400072

Verhagen AM, Ekert PG, Pakusch M, Silke J, Connolly LM, Reid GE, Moritz RL (2000) Identification of DIABLO, a mammalian protein that promotes apoptosis by binding to and antagonizing IAP proteins. Cell 102: 43-53. http://dx.doi.org/10.1016/S00928674(00)00009-X
Waldman T, Kinzler KW, Vogelstein B (1995) p21 is necessary for the p53-mediated G1 arrest in human cancer cells. Cancer Res 55: 51875190. http:// cancerres.aacrjournals.org/content/55/22/5187.full.pdf

Winer J, Jung CK, Shackel I, Williams PM (1999) Development and validation of real-time quantitative reverse transcriptase-polymerase chain reaction for monitoring gene expression in cardiac myocytes in vitro. Anal Biochem 15: 41-49. http://dx.doi.org/10.1006/ abio.1999.4085

Wisdom R, Johnson RS, Moore C (1999) c-Jun regulates cell cycle progression and apoptosis by distinct mechanisms. EMBO J 18: 188-197. http://dx.doi.org/ http://dx.doi.org/10.1093\%2Femboj\%2F18.1.188

Yang SH, Sharrocks AD, Whitmarsh AJ (2013) MAP kinase signalling cascades and transcriptional regulation. Gene 513: 1-13. http://dx. doi.org/ 10.1016/j.gene.2012.10.033 